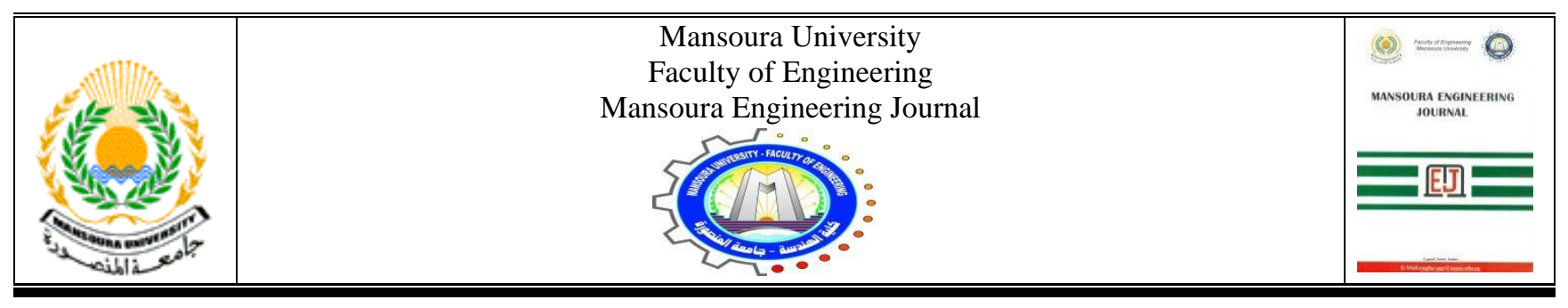

\title{
Impact of Virtual Flow Rate Meter on Brushless DC Motor Based PV-Water Pumping System
}

\author{
Mahmoud Abdo*, Mohammed Saeed and Magdi El-Saadawi
}

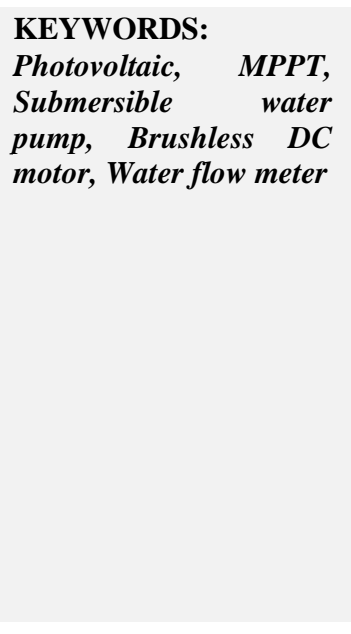

\begin{abstract}
Photovoltaic (PV) water-pumping systems have considerable cost-effective value in rural zones. Virtual flow rate (VFR) meter is a technique to measure the water flow rate through a water pump using a numerical method as a function of the pump head, motor power, and overall efficiency of the pump. VFR meter eliminates the need for rotor speed sensors in PV water pumping systems. In this paper, the virtual flow meter is proposed as a novel reference for improving maximum power point tracking (MPPT) algorithms for PV water-pumping systems. VFR meter removes the expensive flow meter sensors, hence, reducing the overall costs of the system. The VFR will be represented as a new variable in the MPPT algorithm. By replacing the voltage with the instantaneous VFR, the system will operate based on the variation of the VFR meter measurements. Using the physical parameters of a submersible Brushless DC motor pump-based PV water-pumping system, a mathematical model is derived to obtain the input voltage to MPPT algorithm as a function of the instantaneous flow rate. The model is implemented by Mat lab/Simulink software and the results reveal the applicability and efficiency of using the virtual flow meter in MPPT algorithms.
\end{abstract}

\section{INTRODUCTION}

$\mathrm{T}$ THE solar energy can be simply classified into three main categories; PV-power systems, concentrated solar power, and photo-thermal systems. The PV power systems can be categorized as; stand-alone, gridconnected, and hybrid systems. The stand-alone PV system is often used to deliver electric power to rural areas. It consists of PV arrays, a battery bank, a charge controller, and an inverter. The most important application of stand-alone PV systems is PV water-pumping.

The PV water pumping system usually depends on water flow meters to monitor the delivered water volume by the water pump. The water flow sensors are expensive and require periodic maintenance which increases the overall initial and operating costs of the PV water pumping system. A new technique is proposed in this way to deduce the additional cost of the water flow sensors also improving the

Received: (22 May, 2020) - Revised: (4 September, 2020) - Accepted: (20 October, 2020)

* Corresponding author: Mahmoud Abdo, is with the Electrical Engineering department, Faculty of Engineering, Mansoura University, 35516 Mansoura City, Egypt (e-mail: mahmoud.abdo3@eng.mans.edu.eg) readings and performance of the PV water pumping system.

The virtual water flow meter is used recently in many applications like Heating, Ventilation, and Air conditioning (HVAC) [1]. The VFRs in HVAC can replace the flow sensors but only with calibration using other variables resulting in reducing the overall cost of the system [2]. VFR can be applied to the MPPT algorithm as a new reference for operating the system. It can replace rotor speed control as a new and efficient approach. The principle of data-driven virtual flow meters depends on field data collection and mathematical model fitting without any physical parameter definition [3]. The data-driven virtual flow meter concept is valid to be used with brushless DC motor-based PV waterpumping system. First-principles use automatic modeling of multi-phase flows near the well, well's specifications, pipelines, and production chokes [4]. For example, the data required for water-pumping systems include the electric power of the system, total dynamic head, the efficiency of the water pump, and real flow rate.

Mohammed Saeed is with the Electrical Engineering department, Faculty of Engineering, Mansoura University, 35516 Mansoura City, Egypt (e-mail: mohammedsaid@mans.edu.eg).

Magdi El-Saadawi, is with the Electrical Engineering department Faculty of Engineering, Mansoura University, 35516 Mansoura City, Egypt (e-mail:m_saadawi@mans.edu.eg) 
In this paper, the concept of VF metering is utilized in a PV water-pumping system. The proposed system is composed of a PV array, a boost converter with the $\mathrm{P} \& \mathrm{O}$ MPPT algorithm, a brushless DC-motor, and a motor drive. The system voltage is represented as a function of the instantaneous VFR meter and is used as an input for MPPT algorithm. The VFR meter is mathematically calculated using other physical parameters including total dynamic head, voltage, current, and overall efficiency of the water pump [13]. Hence, the VFR meter is considered as a basic parameter in the MPPT algorithm and speed control of the water pump. The operation of the system is based on the measurements of instantaneous VFR. A reference flow rate is added to control the speed of the water pump. The mathematical model of the VFR meter as a reference in MPPT is driven and tested by Matlab/Simulink software. Simulation results show better performance when adding the VFR meter as a new reference to the MPPT algorithm.

The following of this paper is organized as follows. Section 2 presents a literature review. Section 3 describes the architecture of the proposed system whereas section 4 discusses how to model this system. Section 5 shows the mathematical modeling of the VFR meter. Section 6 discusses the proposed control technique. Section 7 illustrates the simulation results. Section 8 discusses the numerical results as an indication of system improvement. Finally, section 8 concluded the paper.

\section{LITERATURE REVIEW}

Nowadays, the PV water-pumping systems became one of the best options for irrigation in rural zones due to its simplicity, long lifetime and other benefits of the system. The PV waterpumping system is composed of PV array and power conditioner with no need to add a huge battery bank capacity for storage [5]. To generate the greatest allowable power from a PV array, it is required to track the points of maximum power according to the incident solar radiation and the operating voltage. To operate the PV module at MPPs using the power converter, a control algorithm is essential. Most used topologies were represented in open-circuit voltage [6], Perturb and Observe (P\&O) [7], Incremental Conductance [8], Predictive control [9], and sliding mode control [10]. The output of the power converter feeds the motor directly or through a motor drive based on the motor's type and operation. Too many topologies were used in the power converters with or without galvanic isolation. There are three power converters' basic types including Buck, Boost, and Buck-Boost converters [11]. Whereas, two main types of motors are available; AC and DC motors [12].

\section{ARCHITECTURE OF THE PROPOSED SYSTEM}

The proposed system is composed of a PV array, a DCDC boost converter with the MPPT algorithm including the virtual water flow rate reference, a brushless DC motor, and a motor drive. A schematic diagram of the proposed system is shown in Figure 1. The DC-DC boost converter raises the DC non-smoothed output voltage from the PV array to a higher smoothed voltage [13]. Output voltage and current readings of the DC-DC boost converter are received by the virtual flow meter model. The meter is connected to the MPPT algorithm as a reference as the MPPT algorithm controls the DC-DC boost converter. The brushless DC motor is controlled through a voltage source inverter (VSI) [14].

The PV array feeds a DC-DC boost converter controlled by the MPPT algorithm including a water flow rate as a new virtual reference then it feeds the motor drive that operates the Brushless DC motor.

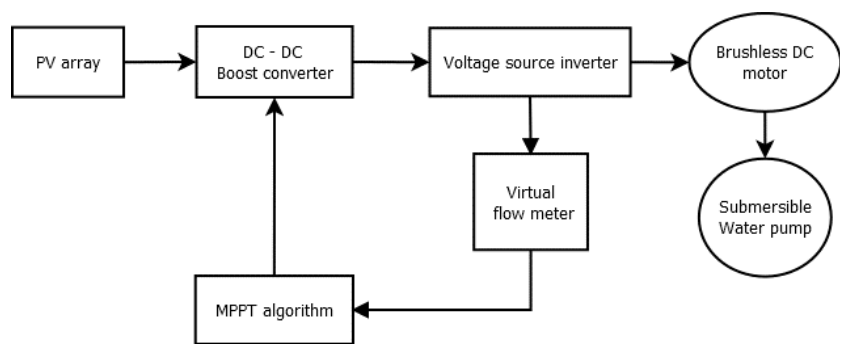

Figure 1: Schematic diagram of the proposed PV water-pumping system

\section{MODELING OF THE PROPOSED SYSTEM COMPONENTS}

The PV power system consists of several modules. The module is a set of PV cells connected in series and parallel and enclosed in a frame to produce given output power. The PV array connections are based on the specific output voltages and currents required by the project [15].

\subsection{Modeling of a PV cell}

The PV-cell is essentially a P-N junction with a large surface area. An ideal PV cell can be modeled as a parallel current source with a diode. The diode mathematically describes the PV-cell characteristics curves. Figure 2 represents the equivalent circuit of an ideal PV-cell. Whereas, the PV-cell output current is represented by (1) [16]

$$
\mathrm{I}=\mathrm{I}_{\mathrm{pv}}-\mathrm{I}_{\mathrm{s}}\left[\exp \left(\frac{\mathrm{q} *\left(\mathrm{~V}+\mathrm{R}_{\mathrm{s}} * \mathrm{I}\right)}{\mathrm{a} * \mathrm{~K} * \mathrm{~T}}\right)-1\right]-\frac{\mathrm{V}+\mathrm{R}_{\mathrm{s}} * \mathrm{I}}{\mathrm{R}_{\mathrm{p}}}
$$

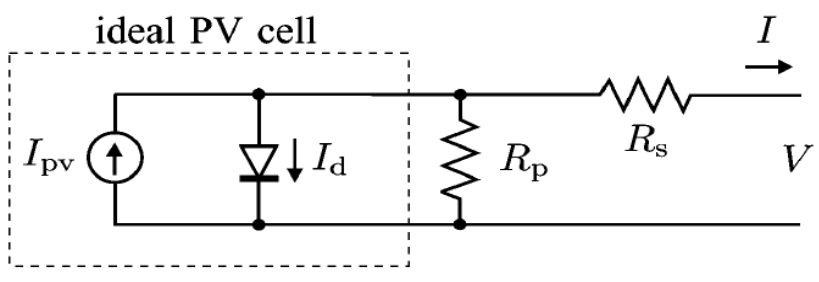

Figure 2: Equivalent circuit of a PV-cell [16]

\subsection{Maximum power tracking}

Maximum power tracking is one of the most effective parameters in extracting better efficiency from the PV panels.

The MPPT is a device composed of two main parts; the power converter, and the control algorithm. MPPT technique can be performed either mechanically or electrically. The mechanical sun tracking is a system that mechanically searches the optimum PV position with respect to the sun. The system uses a DC-motor which is controlled through a 
smart drive unit that receives input-signals from sunlight dependent sensors. The mechanical tracking has a high cost in small-scale projects. On the other hand, the electrical tracking depends on tracking the $\mathrm{I}-\mathrm{V}$ and $\mathrm{P}-\mathrm{V}$ characteristics curves of the PV solar cells in order to obtain the best output power from the module. Figure 3 illustrates the characteristics curves of PV cells under different radiation levels [17].
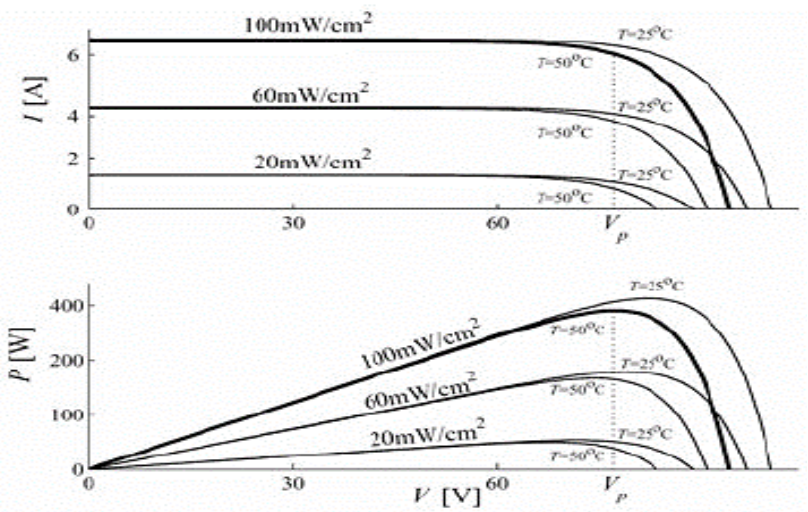

Figure 3: $\mathrm{I}-\mathrm{V}$ and $\mathrm{P}-\mathrm{V}$ characteristics for a $\mathrm{PV}$ module at different radiation levels [17].

To solve the MPP tracking problem, different MPPT methods were established to detect the MPP point whatever the load, or atmospheric conditions [18]. All MPPT methods developed and implemented to track MPP are varied in complexity, sensors speed, cost, required hardware, etc. Finding the voltage automatically or current by using MPPT techniques is the main problem in all of these techniques to discover where the PV array must operate to get the maximum output power under a specified irradiance and temperature [18]. Generally, the MPPT methods can be categorized as conventional, artificial intelligence-based, and hybrid methods.

Although many new MPPT techniques have been applied during the last decade, conventional MPPT techniques are still widely employed as they offer a simple implementation. The most common conventional MPPT methods are Incremental Conductance and Perturb and Observe (P\&O) methods.

\subsubsection{Perturb and observe method}

$\mathrm{P} \& \mathrm{O}$ method is commonly used in estimating the MPP in PV power systems. P\&O method depends basically on variation in power value. A complete flow chart discussing this method is shown in Figure 4. As $\boldsymbol{d P}>\boldsymbol{0}$, the solution moves to MPP and a small increase of the perturb in the same direction will lead to a closer MPP. But when $\boldsymbol{d P}<\boldsymbol{0}$, the solution will move away from MPP and perturb increase will be reversed and moving back toward MPP.

The algorithm increases the duty cycle if the input voltage is fewer than formerly measured one and it has larger input power. The duty cycle decreases to converge to an MPP if the newly measured power is fewer than the formerly measured power and the newly voltage is larger than the eldest voltage [19]. P\&O is the most used MPPT method because it is simple and easy to implement.

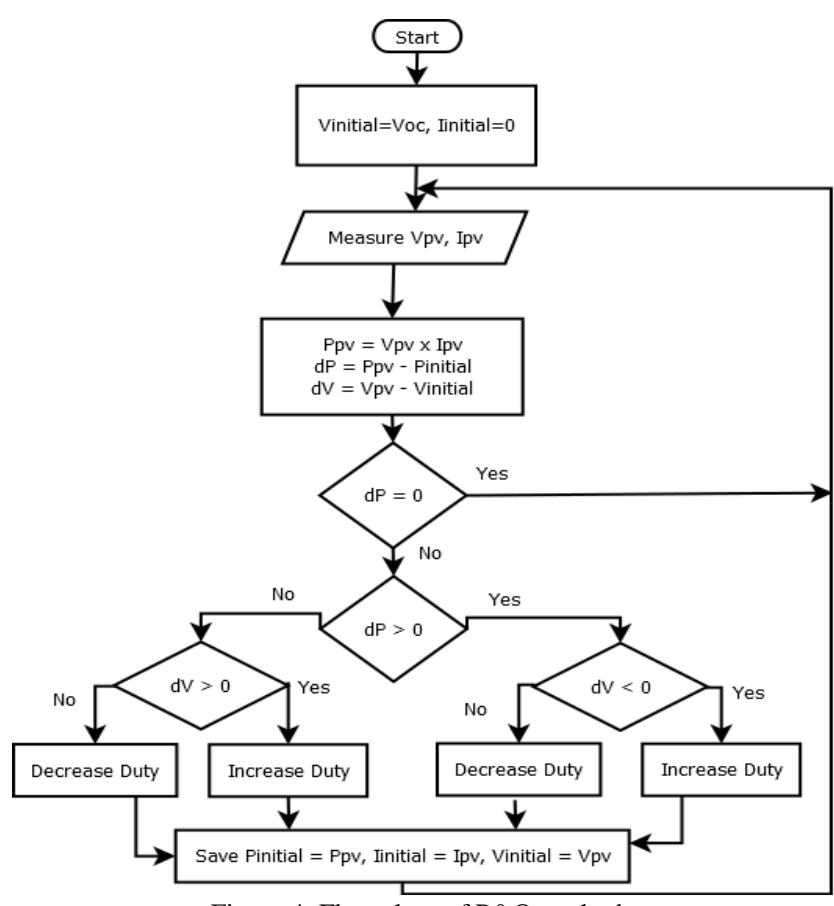

Figure 4: Flow chart of P\&O method

\subsection{Boost converter}

The function of a booster converter is to change the DC voltage level. It steps up voltage (while stepping down current) from its input (supply) to its output (load).

The DC-DC boost converter consists of an inductor, a power electronic switch, a diode, and a smoothing capacitor at the output as explained by Figure 5 .

The switch $\mathrm{S}$ is triggered by output signals of MPPT. In this case, the output voltage of the DC-DC boost converter is a function of input voltage and the output signal from the MPPT algorithm. The output voltage of a DC-DC boost converter in the ideal case can be represented as follows [6].

$$
V_{0}=\frac{V_{s}}{1-D}
$$

Where $V_{o}$ : the output voltage,

$V_{s}:$ the source voltage, and

$D$ :the duty cycle of the triggered signal.

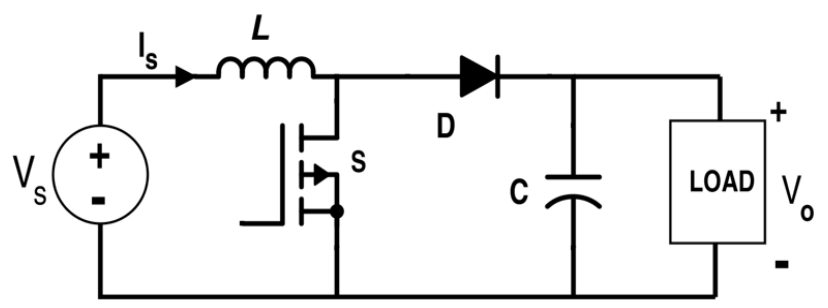

Figure 5: Circuit diagram of DC-DC boost converter.

\subsection{Brushless DC motor}

It is a fact that motor selection is one of the most effective parameters in water-pumping systems. However, in PV pumping systems the motor should be more carefully chosen to ensure a long-life operation in rural areas. The single-phase induction motor has lower power performance compared to 
the permanent magnet DC motor [20]. Nowadays, the permanent magnet brushless DC motor becomes one of the most used motors. Their performance is superior to the brushed DC motors and AC ones for servo and speed control applications. The selection of the motor is now preferable to be brushless DC motor due to their high torque-power characteristics, and their good performance in cloudy days compared to both AC induction and conventional DC motors [21].

The motor drive is a three-phase VSI producing rectangular voltage waveforms to operate the brushless DC motor. A diagram of the brushless pumped DC motor drives is shown in Figure 6. The DC-DC converter is used to optimize the PV array power, BLDC motor-pump speed control, and the soft start. The bulk condenser $\mathrm{C}$ is used in the DC connection to ensure VSI operation of fundamental frequencies [22].

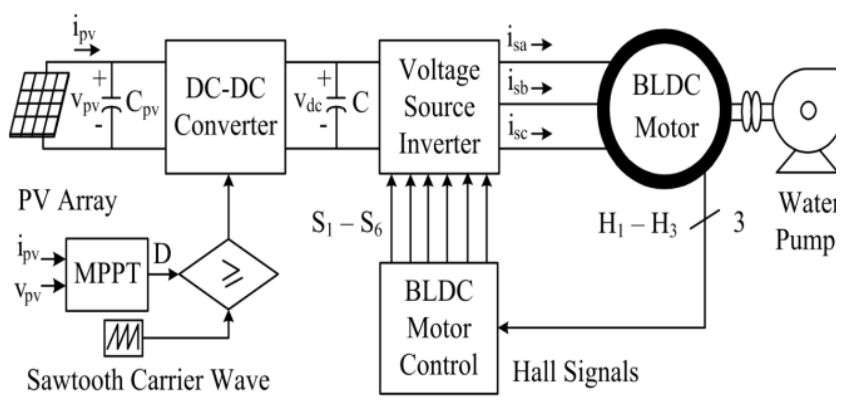

Figure 6: Schematics diagram of a brushless DC motor drives for PV water-pumping [22]

The voltage and current of a brushless DC motor can simply be represented after neglecting the inductance effect as follows:

$$
\begin{aligned}
& V_{A}=I_{A} * R_{A}+e \\
& V_{B}=I_{B} * R_{B}+e \\
& V_{C}=I_{C} * R_{C}+e
\end{aligned}
$$

Where $\mathrm{V}_{\mathrm{A}}, \mathrm{V}_{\mathrm{B}}$, and $\mathrm{V}_{\mathrm{C}}$ are phase voltages of the brushless DC motor, $R_{A}, R_{B}$, and $R_{C}$ are phases' resistances, $I_{A}, I_{B}$, and $\mathrm{I}_{C}$, are currents per phase, and $\mathrm{e}$ is the back-EMF of the phase.

\section{VIRTUAL FLOW METERS}

A virtual meter is a model that uses process conditions for calculating flow rates, rather than using a physical meter. The concept of virtual meter can be applied to any physical parameter using calibrated equations without connecting any additional sensors. The virtual flow calculation is a tool to estimate oil, gas, and water flows from wells without direct measurement. In this section, the principle of the virtual flow meters' operation is introduced, and the mathematical model is driven.

\subsection{Principle of operation}

Flow rates can be calculated mathematically utilizing appropriate measurable variables coupled with calibrated property correlations, instead of using physical flow meters [23]. Figure 7 illustrates a schematic diagram of VFR meter principles.
The VFR receives and converts the power at the frequency and the voltage in the varying frequencies and voltages. This motor derives power from the virtual flow meter at variable frequencies with voltages and pumps with decreased motor and shaft power at variable speeds. The pump produces an increase in water pressure or a pump head and induces a motor shaft power-driven water flow.

A differential pressure transducer can be used to calculate the pump head easily and accurately. The motor power from the VFD control panel is now easy to achieve. The virtual flow meter control panel provides both the motor input power and the virtual flow meter frequency and voltage.

To put it another way, the VFR meter provides the required inputs for motor efficiency calculation. To calibrate the virtual flow meter, a portable, ultrasonic water flow meter is often installed in the system [24].

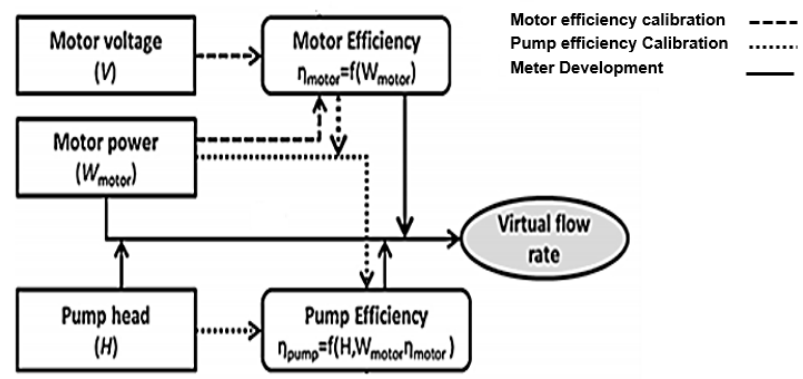

Figure 7: Schematic diagram of water VFR meter [9]

\subsection{Mathematical modeling of a virtual flow meter}

The mathematical model is derived through the power equation as a function of flow rate, gravity, dynamic head, and efficiency as follows.

$$
\begin{aligned}
& P=V * I=\frac{\rho * g * Q * H}{\eta} \\
& V=f(Q)=\frac{Q * H * \rho * g}{I * \eta}
\end{aligned}
$$

Where; $\mathrm{V}$ and $\mathrm{I}$ are the system voltage and current respectively, $\rho$ is the density of the fluid, $g$ is gravity, $Q$ is the instantaneous water flow rate, $\eta$ is the overall efficiency of motor and pump, and $\mathrm{H}$ is the total dynamic head.

The frequency is not included in the equation due to the usage of the brushless DC motor. Using (6), the water flow rate can simply be mathematically calculated using other available parameters with ease.

$$
Q=\frac{V * I * \eta}{H * \rho * g}
$$

\section{PROPOSED CONTROLLER}

Too many topologies can be utilized to control brushless DC motor-based PV water-pumping systems. A lot of models of PV water-pumping systems have been developed. Such simulations models have used climate data to measure the pumped flow rate and they were focused on the various parts of the power conversion chain [25]. Using the water flow rate as a reference in the MPPT algorithm is a new approach to achieve more accurate data for PV water-pumping systems used in irrigation. Replacing the position sensor and speed 
controller in Figure 6 with the VFR in Figure 7; the proposed model is based on monitoring a flow rate reference for required crops and the control is represented in Figure 8.

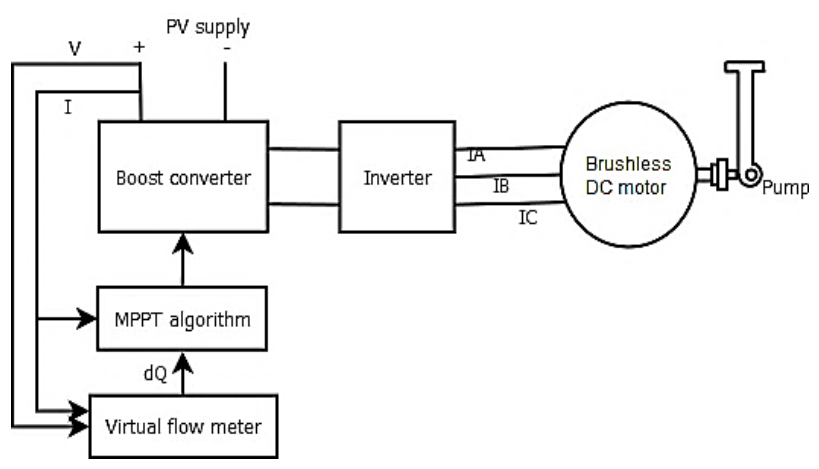

Figure 8: Schematic diagram of a PV system with MPPT-based flow rate meter and brushless DC motor

As explained in section 4, the voltage and flow rate were represented as a function of each other. In the proposed control method, the voltage applied to the MPPT algorithm will be represented as a function of the VFR value. A datadriven VFR meter is chosen. The importance of this meter lies in neglecting the physical processes for which the exact solution can be difficult to find numerically [11].

Using (7) in the $\mathrm{P} \& \mathrm{O}$ algorithm, the voltage variation can be represented as a function of flow rate variation.

$$
\begin{aligned}
& d V=\frac{d Q * H * \rho * g}{I * \eta} \\
& d Q=Q_{r e f}-Q_{a c t}
\end{aligned}
$$

Where $Q_{r e f}$ is the reference value the system is supposed to work at, and $Q_{a c t}$ is the actual value calculated flow rate.

\section{SIMULATION RESULTS AND DISCUSSION}

The proposed system is represented by Mat lab/Simulink software. A test system is used to study the impact of applying VFR meter on output power, rotor speed, and mechanical torque. First, the test system is operated using a conventional MPPT algorithm, then the proposed technique is applied to it. Finally, a comparison is held between the two cases to evaluate the performance of both conventional and proposed systems.

\subsection{Simulation}

The test system is implemented using Mat lab functions linked to Simulink environment. Using the VFR meter, voltage is calculated from (7), and then it is applied to the P\&O MPPT algorithm as illustrated in Figure 9. In this Figure, the current, the required flow rate $\mathrm{Q}$, the total dynamic head $\mathrm{H}$, and the pump efficiency are inputs to the VFR function which is connected directly to the MPPT algorithm.

The complete Simulink model for the test system with conventional MPPT is shown in Appendix A1. Whereas, the complete Simulink model of the PV system with the MPPTbased VFR meter is shown in Appendix A2.

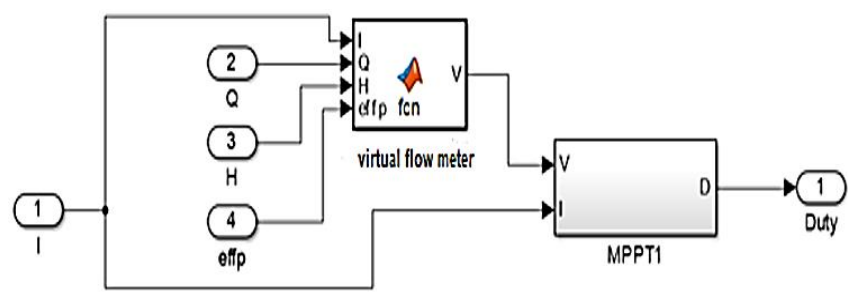

Figure 9: Simulink Representation of Virtual flow connected to MPPT

\subsection{Description of the test system}

A simple test system is used for verifying the proposed technique. The test system is composed of a PV module, a boost converter with MPPT algorithm, and a brushless DC motor coupled to a submersible water pump. The proposed motor type in this study is the Lorentz model with an efficiency of over $90 \%$ and power ratings up to $4 \mathrm{~kW}$. At a water depth of $140 \mathrm{~m}$, the Lorentz model PS2 - 4000 can pump water with a flow rate of $4 \mathrm{~m}^{3} / \mathrm{hr}$. Other depths are available for study when required. The technical numerical data of the system are illustrated in Table 1, whereas the Lorentz brushless DC motor performance over different dynamic heads and power range is shown in Appendix B.

TABLE I

ELECTRICAL DATA OF THE TEST SYSTEM COMPONENTS

\begin{tabular}{c||l||l}
\multicolumn{1}{c|}{ Component } & Electrical data \\
\hline \multirow{3}{*}{ PV module } & Module open-circuit voltage, $\mathrm{V}_{\mathrm{oc}}$ & $39.8 \mathrm{~V}$ \\
\cline { 2 - 3 } & Module short circuit current, $\mathrm{I}_{\mathrm{sc}}$ & $9.6 \mathrm{~A}$ \\
\cline { 2 - 3 } & Maximum power, $\mathrm{P}_{\max }$ & $275 \mathrm{~W}$ \\
\hline \multirow{2}{*}{$\begin{array}{c}\text { Brushless DC } \\
\text { motor (Lorentz) }\end{array}$} & Rated voltage, $\mathrm{V}_{\text {rated }}$ & $240 \mathrm{~V}$ \\
\cline { 2 - 3 } & Rated current, $\mathrm{I}_{\text {rated }}$ & $16 \mathrm{~A}$
\end{tabular}

\subsection{PV water-pumping system with applying conventional $M P P T$}

In this case, the conventional $\mathrm{P} \& \mathrm{O}$ based MPPT is applied to the test system. Using VSI for motor operation, the input current and voltage of the motor are represented in rectangular waveforms with maximum values of applied voltage and current.

The simulation results for the normal operation line to line voltage, stator current, speed of the rotor, and the motor torque is shown in Figure 11. As the electronic switch in the DC-DC boost converter is on, the PV voltage generally drops to zero at a short circuit state. The line to line voltage applied to the brushless DC motor loses its value at $\mathrm{t}=0.35 \mathrm{~s}$ which is repeated along the tested time interval as shown in Figure 11.a. As the line to line voltage applied to the brushless DC motor has a periodic loss, the current also has a periodic loss alternatively as illustrated in Figure 11.b.

It is well known that the speed of the rotor is proportional to the applied voltage. As the system voltage and current have a sudden value loss at different instants, the motor speed faced extreme ripples and sudden variations in values as illustrated in Figure 11.c. This leads to a decrease in the speed of the motor which results in less operational performance. As the torque is proportional to the withdrawn current by the motor, and the stator current waveform is not stable and reaching zero value many times during the period. So, the 
electromagnetic torque approaches zero values during these times as illustrated in Figure 11.d.

The conventional MPPT may affect the motor lifetime and decrease the gross efficiency of the whole PV water-pumping system. So, the conventional MPPT controller for the PV water-pumping systems should be modified for more operational performance.
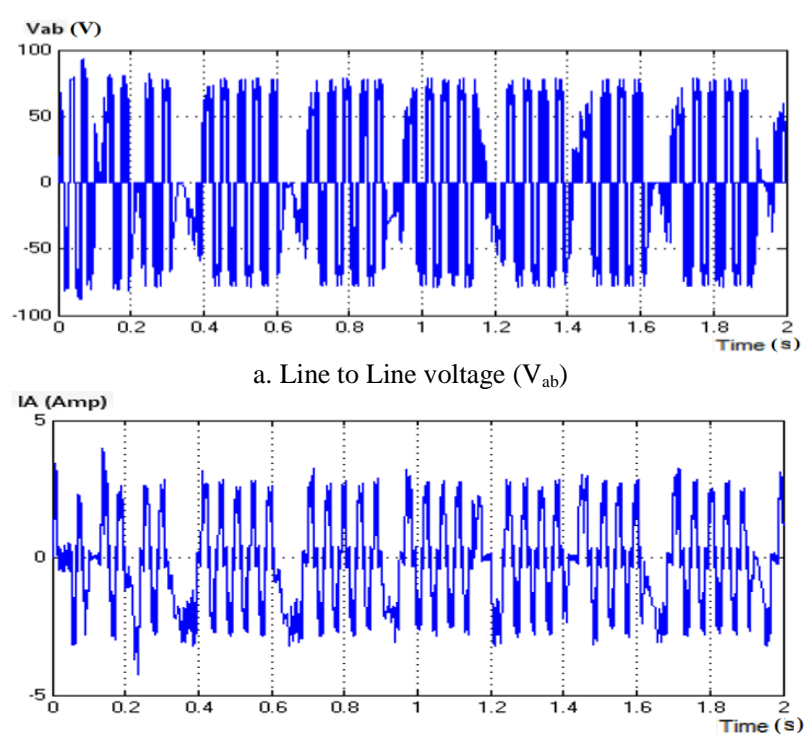

b. Stator current.

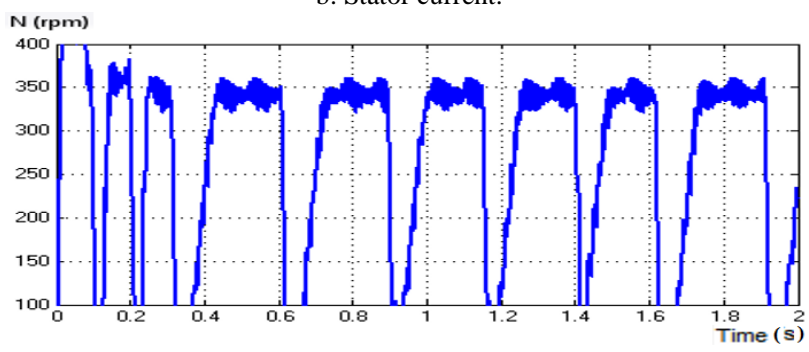

c. Rotor speed.

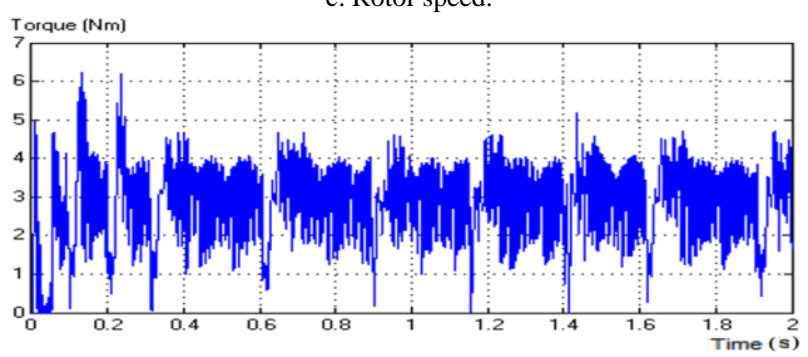

d. Electromagnetic Torque

Figure 11: Simulink results of conventional MPPT system

\subsection{PV water-pumping system with applying the proposed controller}

In this case, the proposed virtual flow meter MPPT controller is applied to the test system. Figure 12 shows the simulation results; the line to line voltage, stator current, speed of the rotor, and the motor torque respectively.

The issue of the PV short circuit during the ON mode of the DC-DC boost converter is solved in the proposed controller. Using the voltage as a function of both VFR and current readings in MPPT algorithm has eliminated the chance of dropping to zero value and the current in a DC-DC boost converter will not reach zero. The MPPT algorithm now has a better range of operating variables although the chopper effect is still existing.

In this case, the measured DC bus voltage applied to MPPT is dependent on the input current, the VFR, the pump head, and the overall efficiency of the water pump. This aids to reach more sensitive measurements in the MPPT which means reaching more enhanced results and more power output is generated from the MPPT algorithm. The enhancement in measured DC bus voltage has affected positively the line to line voltage applied to the brushless DC motor as illustrated in Figure 12.a. The improvement in the voltage waveform directly improves the current waveform as shown in Figure 12.b. So, by applying the proposed modified controller, the line to line voltage and stator current are improved and there is no loss of rotor speed or motor torque as shown in Figures 12.c, 12.d.
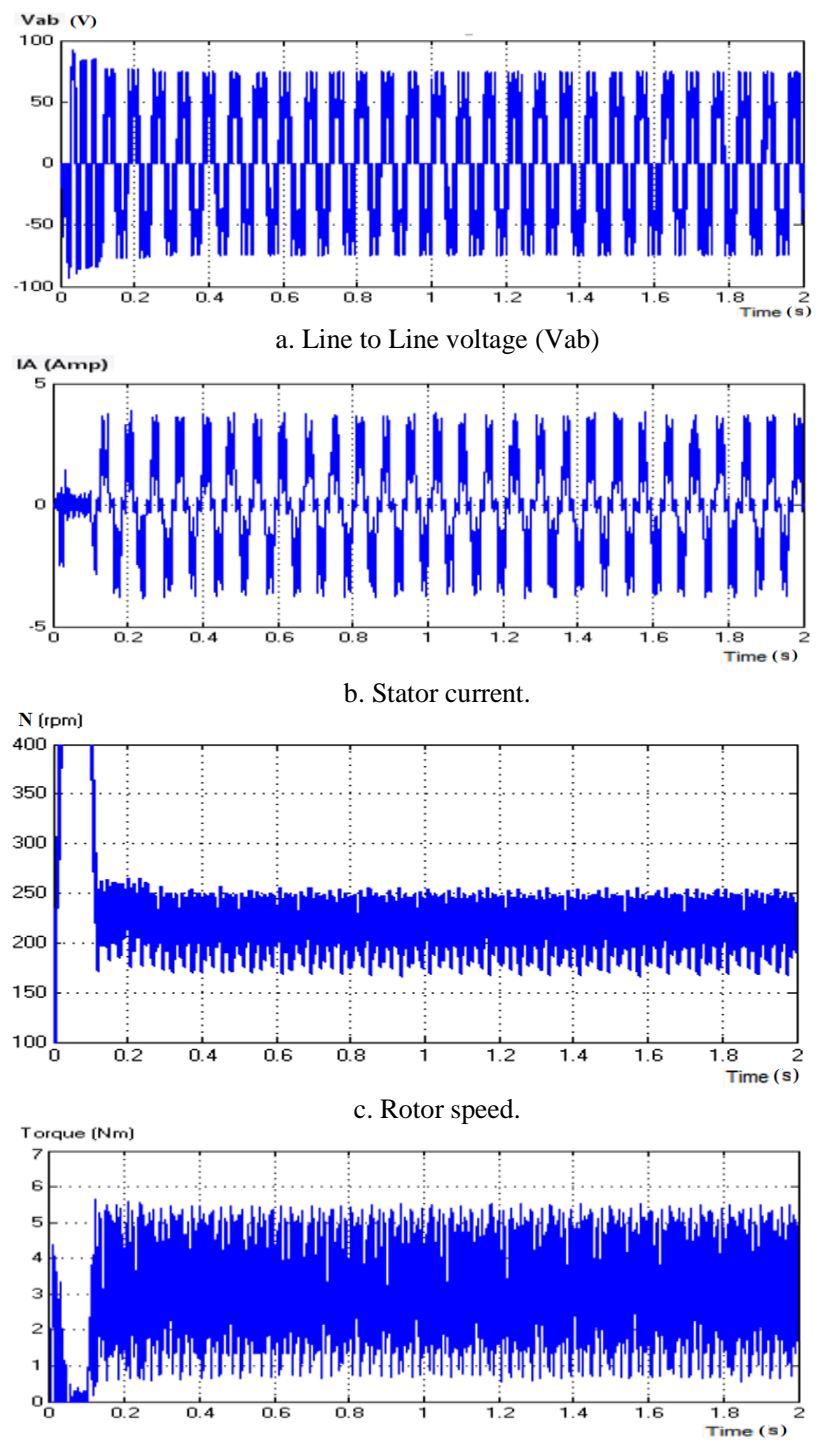

d. Electromagnetic Torque

Figure 12: Simulink results using the MPPT-based VFR meter reference.

\section{RESULT DISCUSSION}

The virtual flow metering technique has proved its ability to improve the overall performance of the PV water pumping system cost-effectively. Table 2 illustrates the readings when 
operating the conventional PV water pumping and the proposed VFR based PV water pumping systems.

For easier numerical comparison root mean square (rms) values are measured. The motor line to line rms voltage in the conventional system reached $36.5 \mathrm{~V}$. However, using the proposed VFR technique the line to line voltage rms reached 39.5V. Stator rms current reached $1.9 \mathrm{~A}$ in the case of a conventional system. and $1.86 \mathrm{~A}$ in the case of using the VFR technique.

Total produced power is known as voltage multiply current. The total produced power by the PV array in the conventional system is equal to $69.35 \mathrm{~W}$. Whereas it is 73.47 $\mathrm{W}$ by using the proposed virtual metering technique. The power produced by the array has improved by around $6 \%$ which allows more produced power.

The torque and speed are oppositely proportional. Numerical results in table 2 show that the speed has increased by around $22 \mathrm{rpm}$ which reduced the torque by 0.3 N.m. $(8 \%$ decrease). The increase in speed meets an increase in delivered water volume. The reduction in torque is an advantage as it indicates lower mechanical stress on the motor with longer lifetime operation.

TABLE II

COMPARISON BETWEEN CONVENTIONAL AND VFR METER-BASED PV WATER-PUMPING SYSTEMS

\begin{tabular}{l||c||c}
\multicolumn{1}{c||}{ Item } & Conventional system & $\begin{array}{c}\text { Proposed virtual flow } \\
\text { meter-based system }\end{array}$ \\
\hline $\begin{array}{l}\text { Motor line to } \\
\text { line, } \mathrm{V}_{\mathrm{ab}}\end{array}$ & $36.5 \mathrm{~V}$ & $39.5 \mathrm{~V}$ \\
\hline $\begin{array}{l}\text { Stator current } \\
\mathrm{I}_{\mathrm{s}}\end{array}$ & $1.9 \mathrm{~A}$ & $1.86 \mathrm{~A}$ \\
\hline $\begin{array}{l}\text { Total } \\
\text { delivered } \\
\text { power, } \mathrm{P}\end{array}$ & $69.35 \mathrm{~W}$ & $73.47 \mathrm{~W}$ \\
\hline $\begin{array}{l}\text { Rotor speed } \\
\mathrm{S}_{\mathrm{m}}\end{array}$ & $200 \mathrm{rpm}$ & $222 \mathrm{rpm}$ \\
\hline $\begin{array}{l}\text { Motor torque } \\
\mathrm{T}_{\mathrm{m}}\end{array}$ & $3.6 \mathrm{~N} . \mathrm{m}$. & $3.3 \mathrm{~N} . \mathrm{m}$.
\end{tabular}

\section{CONCLUSION}

Conventional MPPT for PV water-pumping systems has a big operational issue. As the PV array may be shortcircuited many times during the switching of the DC-DC converter. So, PV voltage drops to zero many times. This issue affected directly the stator current of the motor, the line to line voltage, the motor speed, and motor torque. For a better operation of the whole system, this paper presented a proposed controller by using VFR meter with conventional MPPT to optimize the operation of PV water pumping systems. The proposed controller has been simulated and tested. A better operation with a better-smoothed motor speed in a PV water pumping model using a brushless DC motor was obtained. The proposed controller guarantees motor lifetime for the whole system as it gave lower motor mechanical stress and stable speed. The controller can work effectively in hybrid systems including a battery storage bank, the output of different kinds of sources can be adjusted directly for daily water requirements based on the instantaneous flow rate.

\section{REFERENCES}

[1] G. Wang, K. Kiamehr, and L. Song, "Development of a virtual pump water flow meter with a flow rate function of motor power and pump head" Journal of Energy and Building, Vol. 117, April 2016, pp. $63-70$.

[2] M. Kim, and J. Jeong, "Experimental verification of a virtual water flowmeter applicable to air conditioning systems", Journal of Energy and Buildings, Vol. 155, November 2017, pp. $425-438$.

[3] T. Bikmukhametov, and J. Jäschke, "First Principles and Machine Learning Virtual Flow Metering: A Literature Review", Journal of Petroleum Science and Engineering, Vol. 184, January 2020, Article 106487.

[4] K. Holmås, and A. Løvli, "Flowmanager ${ }^{\mathrm{TM}}$ Dynamic: A Multiphase Flow Simulator for Online Surveillance, Optimization, and Prediction of Subsea Oil and Gas Production", 15th International Conference on Multiphase Production Technology, BHR Group, June 2011.

[5] I. Carrêlo, et.al, "Comparative analysis of the economic feasibility of five large-power photovoltaic irrigation systems in the Mediterranean region", Journal of Renewable Energy, Vol. 145, January 2020, pp. $2671-2682$.

[6] M. Balato, L. Costanzo, A. Schiavo, and M. Vitelli, "Optimization of both Perturb \& Observe and Open Circuit Voltage MPPT Techniques for Resonant Piezoelectric Vibration Harvesters feeding bridge rectifiers", Journal of Sensors and Actuators A: Physical, Vol. 278, August 2018, pp. $85-97$.

[7] R. Alik, and A. Jusoh, "Modified Perturb and Observe (P\&O) with checking algorithm under various solar irradiation", Journal of Solar Energy, Vol. 148, May 2017, pp. 128 - 139.

[8] R. Putri, S. Wibowo, and M. Rifa'i, "Maximum Power Point Tracking for Photovoltaic Using Incremental Conductance Method", Journal of Energy Procedia, April 2015, Vol. 68, pp. $22-30$.

[9] R. Tang, Z. Wu, and Y. Fang, " Configuration of marine photovoltaic system and its MPPT using model predictive control", Journal of Solar Energy, Vol. 158, December 2017, pp. 995-1005.

[10] Kihal, Abbes, et.al, "An improved MPPT scheme employing adaptive integral derivative sliding mode control for photovoltaic systems under fast irradiation changes", Journal of ISA transactions, Vol. 87, April 2019, pp. 297-306.

[11] N. Mohan, T. Undeland, and W. Robbins, "Power Electronics: Converters, Applications, and Design", book, 3rd edition, Copyright (C) 2003 John Wiley \& Sons, Inc.

[12] P. Periasamy, N. Jain, and I. Singh, "A review on development of photovoltaic water pumping system", Journal of Renewable and Sustainable Energy Reviews, Vol. 43, March 2015, pp. 918 925.

[13] K. Rajan, and B. Singh. "BLDC motor-driven water pump fed by solar photovoltaic array using boost converter", Annual IEEE India Conference (INDICON), New Delhi, India, December 2015.

[14] M. Boroujeni, G. Markadeh, and J. Soltani, "Torque ripple reduction of brushless DC motor based on adaptive inputoutput feedback linearization", Journal of ISA transactions, Vol. 70, September 2017, pp. $502-511$.

[15] E. Kandemir, N. Cetin, and S. Borekci, "A comprehensive overview of maximum power extraction methods for PV systems", Journal of Renewable and Sustainable Energy Reviews, Vol. 78, October 2017, pp. 93 - 112.

[16] A. Jordehi, "Parameter estimation of solar photovoltaic (PV) cells: A review", Journal of Renewable and Sustainable Energy Reviews, Vol. 61, pp. $354-371$.

[17] J. Enrique, et.al, "A new approach to obtain I-V and P-V curves of photovoltaic modules by using DC-DC converters", Conference Record of the Thirty-first IEEE Photovoltaic Specialists Conference, January 2005., Lake Buena Vista, FL, USA, 2005, pp. 1769-1772.

[18] P. Bhatnagar, and R. Nema, "Maximum Power Point Tracking Control Techniques: State-of-the-Art in Photovoltaic 
Applications", Journal of Renewable and Sustainable Energy Reviews, Vol. 23, July 2013, pp. 224-241

[19] B. G. Namitha, et.al, "Implementation of MPPT Algorithm for Solar PV cell using P\&O, Incremental Conductance and Constant Voltage Method", International Journal of Scientific Research in Computer Science, Engineering and Information Technology, Vol.4, May 2018, pp. 2456-3307.

[20] M. Shehabi, and T. Iqbal, "Dynamic Modeling, Control, and Analysis of a Solar Water Pumping System for Libya", Journal of Renewable Energy, Vol. 2017, Article ID 8504283, 13 pages, April 2017.

[21] B. Singh, C. Swamy, and B. P. Singh, "Analysis and development of a low-cost permanent magnet brushless DC motor drive for PV-array fed water pumping system", Journal of Solar Energy Materials and Solar Cells, Vol. 51, February 1998 , pp. $55-67$.

[22] R. Kumar, and S. Bhim, "Single-stage solar PV fed brushless DC motor-driven water pump", IEEE Journal of Emerging and Selected Topics in Power Electronics, Vol. 5, September 2017, pp. $1377-1385$.

[23] W. Zufen, et. al., "Accuracy improvement of virtual pump water flow meters using calibrated characteristics curves at various frequencies", Journal of Energy and Buildings, Vol. 191, May 2019, pp. $143-150$.

[24] T. Bikmukhametov, and J. Jäschke, "First Principles and Machine Learning Virtual Flow Metering: A Literature Review”, Journal of Petroleum Science and Engineering, Vol. 184 , January 2020

[25] S. Meunier, et.al, "A validated model of a photovoltaic water pumping system for off-grid rural communities", Journal of Applied Energy, Vol. 241, May 2019, pp. 580 - 591.

[26] LORENTZ. (2016). Brushless DC Motor | LORENTZ. [online] Accessed 30 August 2020:

https://partnernet.lorentz.de/files/lorentz_ps2_productbrochure_en.pdf

\section{Title Arabic:}

$$
\begin{aligned}
& \text { تأثير مقياس معدل التدفق الافتراضي على نظام ضتخ المياه }
\end{aligned}
$$

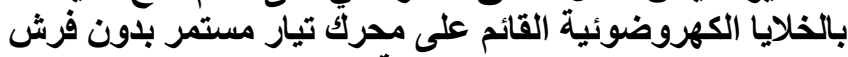

$$
\begin{aligned}
& \text { كربونية }
\end{aligned}
$$

\section{Arabic Abstract:}

تتمتع أنظمة ضخ المياه إعتمادا على الخلايا الكهروضوئية بتكلفة اقتصادية تنافسية

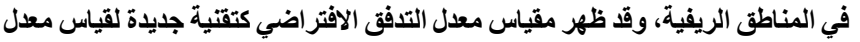

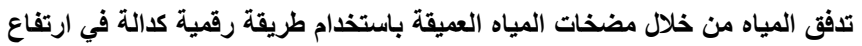

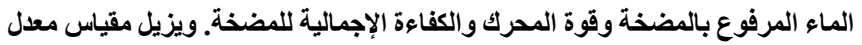

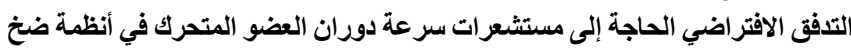

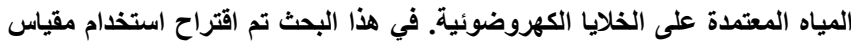

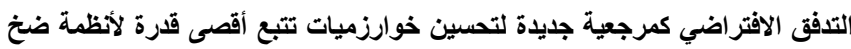

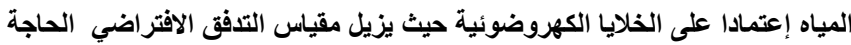

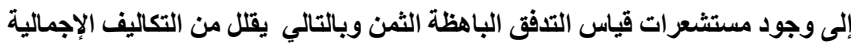

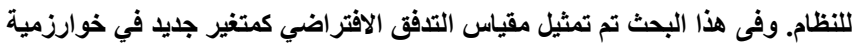

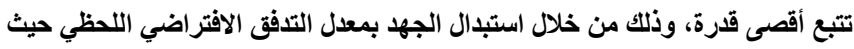

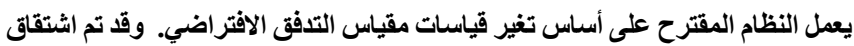

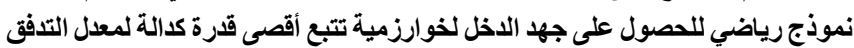

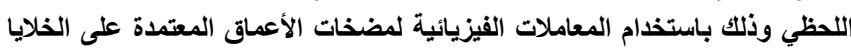
الكهروضوئية والتى تعمل من خلال محرك تيار مستمر لايحتوى على فرش لمرئ كربونية.

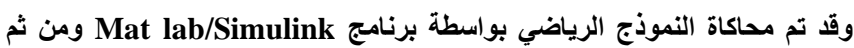
تطبيقه على نظام اختبار حيث أظهرت النتائج قابلية تطبيق النظام المقترح وكائ وكفاءوة

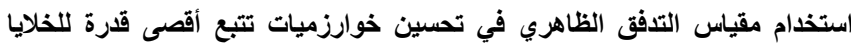

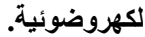

flow $\left[\mathrm{m}^{3} /\right.$ hour $]$

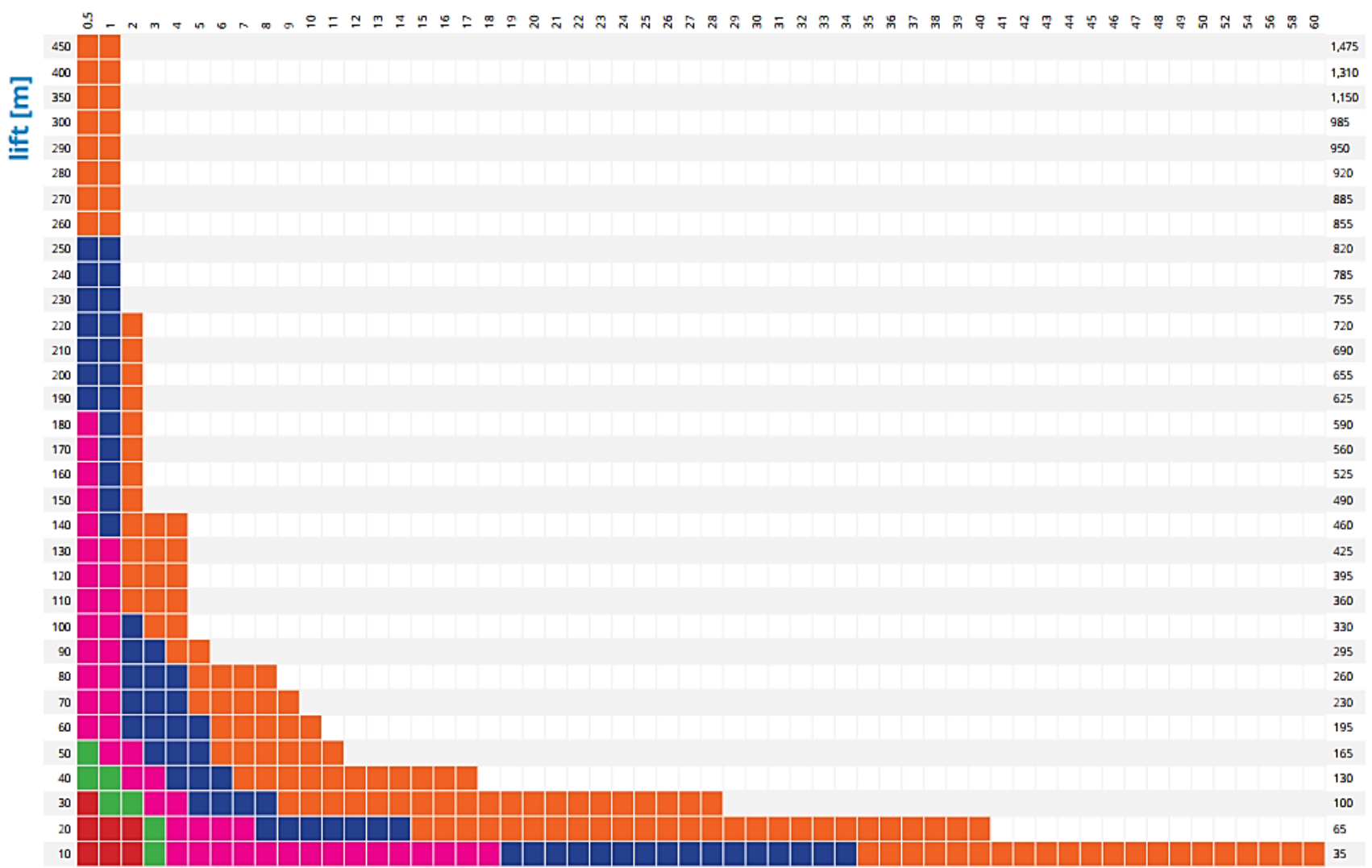

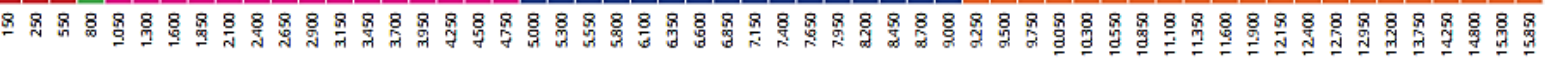

flow [US Gal./hour]

APPENDIX B

Typical Lorentz brushless DC motor pump parameters [26] 


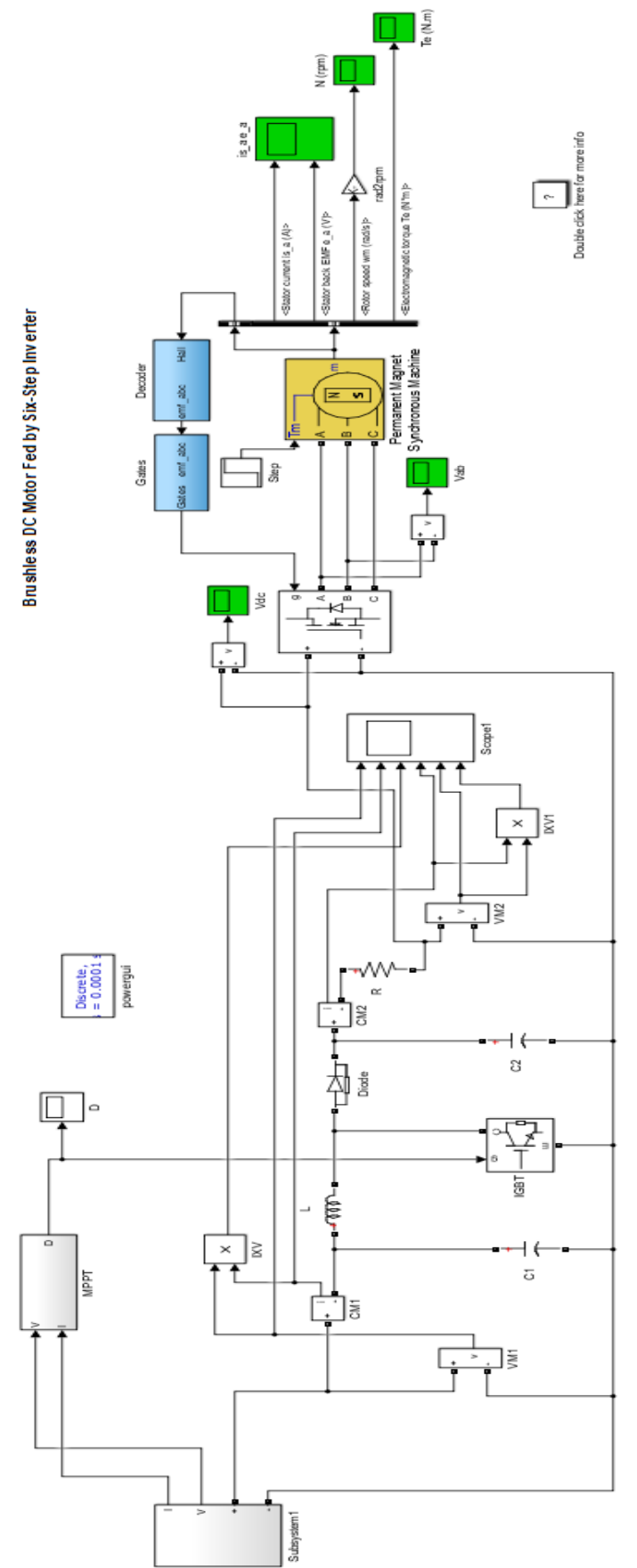

A1: SIMULINK MODEL FOR THE PV TEST SYSTEM UTILIZING CONVENTIONAL MPPT

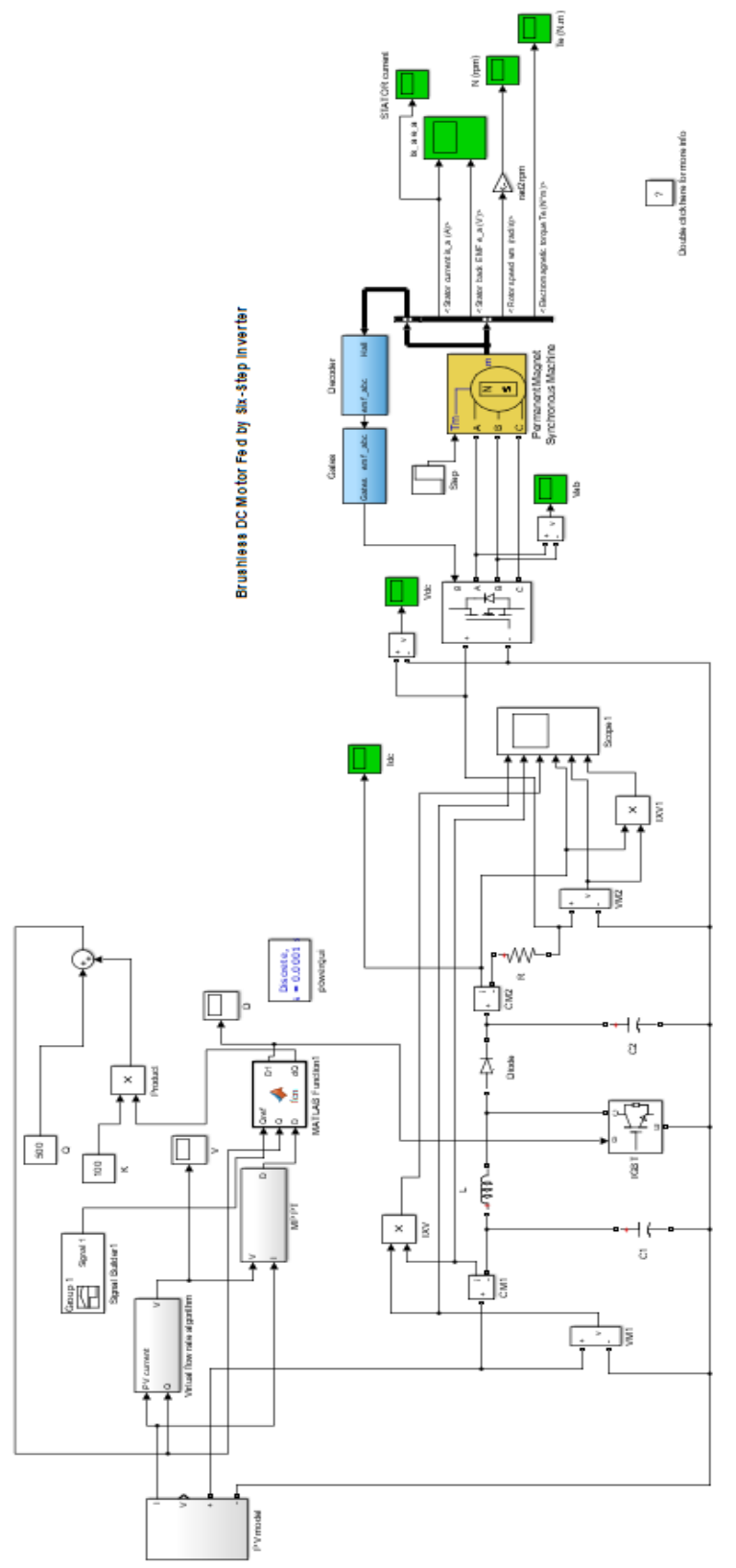

A2: SIMULINK MODEL OF THE COMPLETE SYSTEM WITH THE PROPOSED MPPT CONTROLLER-BASED VFR METER. 